\title{
Muslims and Arabs in Western Politics
}

The "Muslims and Arabs in Western Politics" conference, held at Indiana University, Bloomington, on September 22-24, 2005 and organized by Abdulkader Sinno (assistant professor, political science and Middle Eastern studies, Indiana University), was highly enriching and intellectually stimulating. The two public lectures and five panels, ranging from civil rights and liberties to public perceptions of Muslims, shed light on various aspects of the complexities of this field and acquainted the participants with cutting-edge research by leading scholars from North America and Western Europe.

James Zogby and David Cole delivered the two public lectures on "The Emergent Arab-American Political Constituency" and "Paradigms of Prevention: The Rule of Law and the War on Terror," respectively. Zogby 
covered the development of the Arab-American community's political mobilization and inclusion in mainstream American politics throughout the twentieth century. He narrated his personal experience as a Lebanese immigrant who had experienced the "hard times" of discrimination and exclusion. In addition, he reported on the significant increase in the political mobilization of Muslim minorities in the United States over the last few decades, combined with a growing interest from politicians. His speech ended on a positive note: He is convinced that the community's trajectory will continue to move forward. On the other hand, David Cole's talk focused on the state of constitutional law after $9 / 11$. He argued that substantial negative inroads have been made to the five pillars of the rule of law, namely, equality before the law, transparency of procedures, fairness of procedures, checks and balances, and commitment to basic human rights.

In the first panel, “A Comparative Overview of Political Development of Muslim Minorities in the West,” Yvonne Yazbeck Haddad presented her paper "Muslims in the American Political Maelstrom: 1776-2005.” Jorgen Nielsen discussed "Religion, Muslims, and the State in Britain and France: From Westphalia to 9/11" and called into question traditional typologies that pose Britain as an integrationist model and France as an assimilationist model.

In the second panel, "Participation, Cooption, or Marginalization? Muslims and the Different Institutions of the E.U. and the U.S.,” Abdulkader Sinno posed an intriguing question: "Is There a Glass Ceiling for Muslims in American Politics?” He posited possible explanations for the absence of any nationally elected Muslim officials. Data on the number of elected Muslim members of selected western parliaments suggest that the electoral system, whether the country has a first-past-the-post or a proportional representation system, along with the size of districts and pressure from certain Christian and Jewish groups, seems to impact the number of elected Muslims. On the other hand, Christopher Soper examined why the state's accommodation of Muslim religious practices differed in three West European countries. Overlapping extensively with his recent co-authored book, Explaining the Accommodation of Muslim Religious Practices in France, Britain, and Germany, Soper presented the important addition of four possible scenarios of how this relationship might look in the future.

Panel 3 focused on a highly debated issue, particularly after 9/11: “Are There Tradeoffs between Security and Civil Rights and Could Both Be Enhanced Simultaneously?" David Cole spoke on "Balancing Liberty and Security for All," and was followed by Kent Roach, who, in his paper 
“Canadian National Security Policy and Canadian Muslim Communities,” analyzed Canada's national security and immigration policies post-9/11, especially their effects on Canada's Muslim minorities. Lastly, Anja Dalgaard-Nielsen analyzed "Security and Civil Liberties in the European Union.”

Panel 4 was on "Comparative Attitudes towards Political Mobilization and Participation among Western Muslim Minorities.” Zahid Bukhari talked on "Ethnicity and Muslim Political Experience in the United States," and Jocelyne Cesari presented a comparative paper titled "Public Discourse on Islam: A Transatlantic Comparison." The last paper of this panel, "The Racialization of Arab and Muslim Americans: 9-11 and Civil Liberties,” belonged to Amaney Jamal, who examined why there is extensive support for policies that target and discriminate against Arab and Muslim Americans. She argued that the most durable explanation for the sustained support for infringing upon civil rights and liberties is the racialization of Arabs as the "enemy other," along with such domestic policies and geopolitical realities as wars taking place in these populations' native lands.

The conference's final panel, "Public Perceptions of Muslim Minorities in the West," began with Erik Nisbet's “Shaping the Islamic Threat: The Influence of Ideology, Religiosity, and Media Use on U.S. Public Opinion toward Islam and Muslim Americans” (co-authored with James Shanahan and Ronald Ostman) and was followed by Paul Sniderman's "Multi-culturalism, Muslims, and Identity Politics.” Nispet presented the findings of a November 2004 national survey that measured the impact of Christian religiosity, the mass media's use of the public's perception of Muslims and Islam as well as support for the restrictive policies directed at Muslims. He reported that Christian religiosity, conservative ideology, Republican party affiliation, and exposure to television all impact the public's perceptions of Muslims.

Overall, this timely conference provided an opportunity for participants to exchange cutting-edge research on various topics concerning Muslims in the West. I believe that the presentations revealed the need to conduct extensive cross-national studies on the experiences of Muslim minorities in Europe and North America. Even though a few such studies have been conducted, they are rather small in scale and limited to only two or three countries. Rigorous research and findings are still waiting to be undertaken. 